Jurnal Ilmu-Ilmu Peternakan 25 (1): 42 - 46

ISSN: 0852-3581

E-ISSN : 9772443D76DD3

CFakultas Peternakan UB, http://jiip.ub.ac.id

\title{
Tampilan kualitas susu sapi perah akibat imbangan konsentrat dan hijauan yang berbeda
}

\author{
Suhendra, D ${ }^{1}$, G. T. Anggiati ${ }^{2}$, S. Sarah ${ }^{2}$, A. F. Nasrullah ${ }^{2}$, A. Thimoty ${ }^{2}$ dan D. W. C. \\ $\mathrm{Utama}^{2}$ \\ ${ }^{1}$ Program Studi S-2 Magister Ilmu Ternak \\ ${ }^{2}$ Program Studi S-1 Peternakan \\ Fakultas Peternakan dan Pertanian Universitas Diponegoro \\ danes_suhendra@yahoo.co.id
}

\begin{abstract}
The aim of this study was to assess the optimal balance ration of concentrate and forage to improve dairy milk production. The research was conducted at regional operational unit Mulyorejo, Barukan village, Tengaran Sub District, Semarang Regency, and Banyu Aji Cooperative, Getasan Sub District, Semarang Regency. Data was analyzed at Feed Nutrition Science Laboratory, Faculty of Animal Husbandry and Agriculture, Diponegoro University Semarang. The research started from June 29 to July 31, 2014. The materials of this research were 12 Friesian Holstein dairy cows in second and third months of lactation with average estimated body weight $408.5 \pm 30.86 \mathrm{~kg}$ (Coefficient of Variance $(\mathrm{CV})=10.68 \%$ ) with average milk production around 9.3 \pm 1.01 liters $(\mathrm{CV}=14.33 \%)$. The study was experimental research with completely randomized design using three treatments, i.e. T0 (50\% of concentrate and $50 \%$ of forage), $\mathrm{T} 1$ (45\% of concentrate and $55 \%$ of forage) and T2 (40\% of concentrate and $60 \%$ of forage). The results showed that $\mathrm{T} 2 \mathrm{had}$ a significant effect on milk fat content $(\mathrm{P}<0.05)$, solid non fat $(\mathrm{SNF})$ content $(\mathrm{P}<0.05)$, milk protein content $(\mathrm{P}<0.01)$ and milk lactose content $(\mathrm{P}<0.05)$. This study concluded that the optimal balance ration of concentrate and forage to improve milk performance consisted of $40 \%$ of concentrate and $60 \%$ of forage.
\end{abstract}

Keywords: Dairy cow, NDF, milk fat, solid non fat

\section{PENDAHULUAN}

Kualitas susu peternakan rakyat di Indonesia sebagian besar belum memenuhi persyaratan mutu yang telah ditentukan oleh Badan Standarisasi Nasional (BSN), sehingga banyak yang kalah bersaing dengan susu produk perusahaan besar. Salah satu penyebab buruknya kualitas susu peternakan rakyat adalah karena peternak tidak memperhatikan imbangan antara konsentrat dan hijauan dalam ransum ternak sapi perah. Komponen makro penyusun susu antara lain lemak dan Solid Non Fat (SNF) yang terdiri dari protein, laktosa, mineral, vitamin dan bahan lainnya. Lemak susu menyebabkan rasa susu menjadi gurih, sedangkan laktosa susu menyebabkan susu terasa manis. Protein susu yang sebagian besar berupa kasein berperan untuk meningkatkan kecerdasan konsumen susu. Hal ini yang mendorong beberapa Industri Pengolah 
Susu (IPS) menentukan harga susu Sebagian besar peternakan rakyat di Indonesia, khususnya di Jawa Tengah tidak memperhatikan imbangan konsentrat dan hijauan dalam ransum ternak sapi perah. Sapi perah laktasi seharusnya mengkonsumsi hijauan lebih banyak dibandingkan konsentrat untuk menaikkan kualitas susunya, karena hijauan mengandung serat kasar yang tinggi. Salah satu kandungan serat kasar yang berpengaruh dalam kualitas susu adalah Neutral Detergent Fiber (NDF). Keberadaan NDF dalam ransum sapi perah sangat erat hubungannya dengan tampilan lemak susu dan SNF sapi perah. Ransum yang memiliki kandungan NDF terlalu tinggi menyebabkan palatabilitas pakan menurun, sehingga ternak tidak mengkonsumsi pakan secara optimal sesuai dengan kebutuhannya. Kandungan NDF yang rendah dalam ransum menyebabkan kebutuhan nutrisi bagi ternak berkurang, terutama volatile fatty acid (VFA) yang menghasilkan asam asetat, butirat, propionat dan energi sebagai bahan dasar lemak susu dan SNF, terutama laktosa.

Kandungan NDF yang tinggi dapat menghasilkan kadar lemak susu yang tinggi, karena serat kasar didalam rumen akan didegradasi oleh mikroba rumen sehingga menghasilkan asam asetat yang lebih tinggi dibandingkan asam propionat (Pangestu dkk, 2003). VFA digunakan sebagai sumber energi dan kerangka karbon bagi pembentukan protein (Ensminger, 1992). Asam asetat dan asam butirat akan masuk ke peredaran darah menuju hati untuk diubah menjadi asam lemak, selanjutnya masuk kedalam sel-sel sekresi ambing untuk sintesis lemak susu (Mutamimah dkk., 2013). Asam propionat cenderung digunakan untuk sintesis laktosa susu, sehingga berpengaruh terhadap nilai bahan kering berdasarkan kadar lemak dan protein.

tanpa lemak susu (Prawirokusumo, 1993). Asam propionat akan masuk kedalam hati, lalu diubah menjadi glukosa untuk prekursor laktosa susu.

Berdasarkan latar belakang tersebut, maka penelitian ini bertujuan untuk membandingkan imbangan antara konsentrat dan hijauan dalam ransum yang optimal untuk dapat memperbaiki tampilan kualitas susu sapi perah . Hasil penelitian ini diharapkan dapat memberikan informasi mengenai imbangan konsentrat dan hijauan yang optimal untuk meningkatkan kualitas susu sapi perah, sehingga dapat diaplikasikan oleh peternak sapi perah rakyat.

\section{MATERI DAN METODE}

Penelitian mengenai tampilan kualitas susu sapi perah akibat imbangan antara konsentrat dan hijauan yang berbeda telah dilaksanakan di Unit Pelaksana Teknis Daerah Pembibitan Ternak Mulyorejo Desa Barukan Kecamatan Tengaran Kabupaten Semarang dan Koperasi Banyu Aji Kecamatan Getasan Kabupaten Semarang selama 33 hari dimulai tanggal 29 Juni hingga 31 Juli 2014.

Ternak yang digunakan sebagai materi percobaan adalah sapi perah freisian holstein $(\mathrm{FH})$ sebanyak 12 ekor yang terdiri dari sapi laktasi pada bulan ke II dan III dengan pendugaan bobot badan rata-rata $408,5 \pm 30,86 \mathrm{~kg}(\mathrm{CV}=$ $10,68 \%$ ) dan produksi susu rata-rata $9,3 \pm 1,01$ liter $(\mathrm{CV}=14,33 \%)$. Perlakuan pakan yang digunakan dalam penelitian ini adalah:

$\mathrm{T} 0=$ konsentrat $50 \%+$ hijauan $50 \%$

$\mathrm{T} 1=$ konsentrat $45 \%$ + hijauan $55 \%$

$\mathrm{T} 2=$ konsentrat $40 \%+$ hijauan $60 \%$

Kebutuhan bahan kering (BK) yang digunakan adalah 3,5\% dari bobot badan rata-rata (Yani dan Purwanto, 2006). Analisis bahan pakan dan susu 
hasil percobaan dilakukan di Laboratorium Ilmu Nutrisi Pakan, Fakultas Peternakan dan Pertanian, Universitas Diponegoro, Semarang. Alat yang digunakan adalah timbangan digital gantung, meteran, ember stainlis, gelas ukur, botol dan kotak pendingin, lactoscan milk analyzer buatan Bulgaria dengan kepekaan dua digit di belakang koma (1/100) dalam satuan persen untuk menguji kualitas susu.

Rancangan percobaan yang digunakan dalam penelitian ini adalah Rancangan Acak Lengkap sesuai dengan prosedur Hanafiah (1994), dengan model matematika:

$Y_{i j}=\mu+\tau_{i}+\varepsilon_{i j}$
Keterangan:

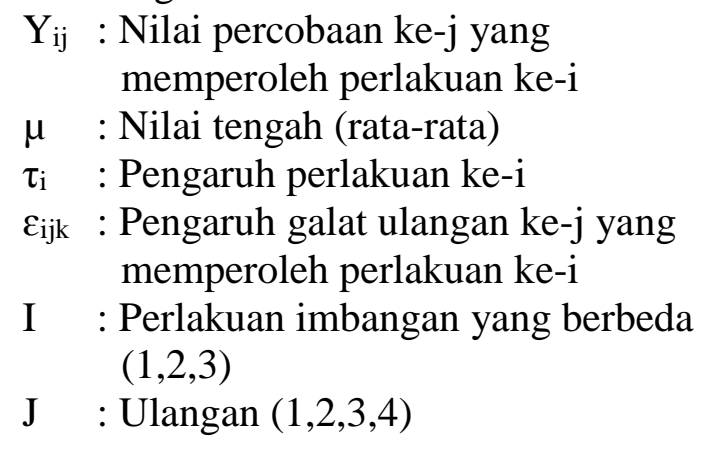

\section{HASIL DAN PEMBAHASAN}

Tabel 1 menunjukkan rataan kualitas susu yang dilihat dari beberapa parameter yakni lemak, SNF, protein dan laktosa.

Tabel 1. Rataan kualitas susu sapi perlakuan T0, T1, dan T2.

\begin{tabular}{lccc}
\hline \multirow{2}{*}{ Parameter } & \multicolumn{3}{c}{ Perlakuan } \\
\cline { 2 - 4 } & T0 & T1 & T2 \\
\hline Lemak (\%) & $3,28^{\mathrm{a}}$ & $3,45^{\mathrm{ab}}$ & $3,51^{\mathrm{b}}$ \\
SNF (\%) & $7,31^{\mathrm{a}}$ & $7,75^{\mathrm{b}}$ & $7,83^{\mathrm{b}}$ \\
Protein (\%) & $2,53^{\mathrm{a}}$ & $2,68^{\mathrm{b}}$ & $2,69^{\mathrm{b}}$ \\
Laktosa (\%) & $3,82^{\mathrm{a}}$ & $4,06^{\mathrm{b}}$ & $4,12^{\mathrm{b}}$ \\
\hline
\end{tabular}

Keterangan : Superskrip dengan huruf yang berbeda pada baris yang sama menunjukkan berbeda nyata $(\mathrm{P}<0,05)$

\section{Kadar lemak susu}

Analisis statistik menunjukkan bahwa rata-rata kadar lemak susu pada perlakuan $\mathrm{T} 2$ berbeda nyata dengan $\mathrm{T} 0$ $(\mathrm{P}<0,05)$. Kadar lemak susu mengalami peningkatan pada perlakuan T2 sebesar $0,23 \%$. Hal ini disebabkan karena serat kasar yang dikonsumsi sapi berada pada jumlah yang optimal yang kemudian difermentasi oleh mikroba rumen sehingga menghasilkan asam asetat yang optimal sebagai bahan dasar lemak susu.

Rata-rata tampilan lemak susu pada T0 dan T1 tidak berbeda, demikian juga T1 dengan T2. Kadar lemak pada T1 tidak memiliki perbedaan yang nyata dengan T0 diduga karena kandungan serat kasar yang dikonsumsi oleh sapi hanya sedikit, sehingga asam asetat dan butirat yang dihasilkan juga sedikit. Jumlah asam asetat dan butirat yang sedikit ini berdampak terhadap kadar lemak susu yang rendah.

Asam asetat dan butirat merupakan bahan dasar penyusun lemak rantai panjang pada susu. Semakin tinggi kadar serat kasar pakan, maka semakin tinggi pula kadar asam asetat dalam rumen hasil perombakan mikroba rumen.

Tanuwiria dkk (2008) menyatakan bahwa kadar lemak susu dipengaruhi oleh serat pakan dan hasil metabolismenya berupa asetat. Ransum yang mengandung serat kasar tinggi akan banyak menghasilkan asam asetat yang merupakan prekursor sintesis de 
novo lemak susu di ambing. Lu et al. (2005) menambahkan bahwa serat pakan secara kimiawi dapat digolongkan menjadi serat kasar, Neutral Detergent Fiber (NDF), Acid Detergent Fiber (ADF), Acid Detergent Lignin (ADL), selulosa dan hemiselulosa.

Aisyah (2009) menambahkan bahwa mikroba rumen dapat tumbuh optimal dan berfungsi optimal dengan enzim selulase yang dihasilkannya. Menurut Tyler and Ensminger (2006), sumber pembentukan lemak susu ada tiga yaitu glukosa, triasilgliserol dari bahan pakan atau asam lemak yang disintesis oleh kelenjar ambing.

\section{Kadar protein, laktosa dan solid non fat susu}

Analisis statistik menunjukkan bahwa rata-rata kadar SNF susu pada perlakuan T0 dengan T1 dan perlakuan T0 dengan $\mathrm{T} 2$ berbeda nyata $(\mathrm{P}<0,05)$. Kadar SNF susu mengalami peningkatan pada perlakuan T2 sebesar $0,52 \%$. Hal ini disebabkan kandungan serat kasar yang dikonsumsi sapi perah pada T2 lebih banyak sehingga proses fermentasi oleh mikroba rumen menghasilkan VFA yang lebih banyak. Salah satu bagian dari VFA adalah asam propionat yang merupakan bahan dasar laktosa susu. VFA juga digunakan sebagai sumber energi dan kerangka karbon bagi pembentukan protein, dimana komponen penyusun SNF susu antara lain protein dan laktosa.

Sapi dengan perlakuan T1 diduga memiliki jumlah serat kasar yang terkonsumsi sedikit sehingga menghasilkan asam propionat dan energi yang sedikit. Hal ini sesuai dengan pendapat Ensminger (1992) yang menyatakan bahwa asam lemak terbang digunakan sebagai sumber energi dan kerangka karbon bagi pembentukan protein. Sarwiyono dkk,
(1990) menambahkan bahwa SNF atau bahan kering tanpa lemak adalah semua jumlah komponen penyusun susu dikurangi air dan kadar lemak, yaitu terdiri dari protein, laktosa, mineral dan vitamin. Prawirokusumo (1993) menyatakan bahwa asam propionat mayoritas digunakan untuk sintesis laktosa susu, sehingga berpengaruh terhadap nilai bahan kering tanpa lemak susu. Prihartini dan Khotimah (2011) menambahkan bahwa degradasi VFA yang tinggi seiring dengan meningkatnya produksi $\mathrm{NH}_{3}$ sehingga $\mathrm{NH}_{3}$ dapat digunakan untuk sintesis protein mikroba rumen.

\section{KESIMPULAN DAN SARAN}

Imbangan konsentrat dengan hijauan yang paling optimal untuk meningkatkan kualitas susu sapi perah adalah 40\% konsentrat dan $60 \%$ hijauan. Oleh karena itu diperlukan penelitian lebih lanjut mengenai metode pemberian konsentrat dan hijauan yang paling baik untuk meningkatkan kualitas susu sapi perah sehingga dapat lebih melengkapi hasil penelitian ini.

\section{DAFTAR PUSTAKA}

Aisyah, S. 2009. Tingkat produksi susu dan kesehatan sapi perah dengan pemberian Aloe barbadensis miller. Gamma 7 (1) : 50-60.

Ensminger, M. E. 1992. The Stockman's Handbook. $7^{\text {th }}$ Ed., The Interstate Printers and Publishers, Inc. Danville, Illinois.

Hanafiah, K. A. 1994. Rancangan percobaan teori dan aplikasi. PT Raja Gramafindo Persada, Jakarta.

Lu, C. D., J. R. Kawas, dan O. G. Maghoub. 2005. Fiber digestion and utilization in goats. Small. Rumin. Res 60: 45-65. 
Mutamimah, L., S. Utami dan A. T. A. Sudewo. 2013. Kajian kadar lemak dan bahan kering tanpa lemak susu kambing Sapera di Cilacap dan Bogor. J. Anim. Sci. 1 (3) : 874-880.

Pangestu, E., T. Toharmat, dan U. H. Tanuwiria. 2003. Nilai nutrisi ransum berbasis limbah industri pertanian pada sapi perah laktasi. J. Indon. Trop. Anim. Agric. 28 (3): 166-171.

Prihartini, I., dan K. Khotimah. 2011. Produksi probiotik rumen berbasis bakteri lignochloritik dan aplikasinya pada ternak sapi perah. Gamma 7 (1): 27-31.

Prawirokusumo, S. 1993. Ilmu gizi komparatif. Edisi pertama. Badan Penerbitan Fakultas Ekonomika dan Bisnis Universitas Gadjah Mada, Yogyakarta.

Sarwiyono, P., Surjowardojo dan T. E. Susilorini. 1990. Manajemen produksi ternak perah. Fakultas
Peternakan Universitas Brawijaya, Malang.

Tanuwiria, U. H., A. Yulianti, dan R. Tawaf. 2008. Pengaruh imbangan jerami padi fermentasi dan konsentrat dalam ransum terhadap fermentabilitas dan kecernaan in vitro serta performans produksi pada sapi perah laktasi. Fakultas Peternakan Unpad. Seminar Nasional. (Diakses tanggal 16 Agustus 2014 pada situs http://pustaka.unpad.ac.id/archiv es/124784.pdf).

Tyler, H. D. and Ensminger, M. E. 2006. Dairy cattle science. $4^{\text {th }}$ Ed. Pearson Prentice Hall, Ohio.

Yani, A. dan B. P. Purwanto. 2006. Pengaruh iklim mikro terhadap respon fisiologis sapi peranakan Fries Holland dan modifikasi lingkungan untuk meningkatkan produktivitasnya. Media Peternakan 29 (1): 35-46. 